[Review Paper]

\title{
New Strategy for Precise Synthesis of Polyoxometalate Catalysts with Designed Active Sites
}

\author{
Kosuke SuZUKI* , Noritaka Mizuno, and Kazuya YAMAGUCHI \\ Dept. of Applied Chemistry, School of Engineering, The University of Tokyo, 7-3-1 Hongo, Bunkyo-ku, Tokyo 113-8656, JAPAN \\ (Received May 11, 2020)
}

\begin{abstract}
In this paper, we introduce our recent research on the precise synthesis of molecular metal oxide nanoclusters, i.e., polyoxometalates (POMs) with precisely engineered active site structures, and their application to organic synthesis reactions. Specifically, using lacunary POMs with coordination sites as molecular templates or multidentate ligands in organic solvents, we established a precise inorganic synthesis method that allowed us to engineer active site structures and unique functions. In organic solvents, the protonation states of lacunary POMs and the dissolved states of metal species can be controlled; thus, we can design functional inorganic materials with the controlled number, arrangement, and oxidation states of metal atoms. Furthermore, using the synergetic effect of POMs with metals or substrates, we pioneered a new methodology of designing POM catalysts to produce catalysts with new reactivity and high performance. On the basis of these methods, visible-light-responsive redox catalysts were developed using intramolecular charge transfers.
\end{abstract}

\section{Keywords}

Polyoxometalate, Metal oxide, Catalysis, Photocatalysis, Inorganic synthesis

\section{Introduction}

The development of new catalyst technologies that can precisely design the structures and functions of catalysts is essential to allow highly efficient, selective, and energy-saving chemical reactions for sustainable society. Metal oxides exhibit unique properties that depend on the type, composition, oxidation states of constituent metals, and their structures; metal oxides have a wide range of outstanding properties for applications in many fields of science such as catalysis, magnetism, optics, and electronics ${ }^{1), 2}$. If it is possible to realize the synthesis of metal oxides that can precisely and freely control the number, composition, and arrangement of metal atoms, the development of novel inorganic materials can be expected by creating active site structures by controlling electronic states and synergistic functional integration. However, using typical synthesis methods, it is difficult to synthesize metal oxides with precisely designed structures and functions.

Polyoxometalates (POMs) are molecular metal oxide nanoclusters that show a wide range of structures and properties ${ }^{3), 4)}$. They exhibit unique chemical and physical properties, including acid-base and redox properties, which makes them attractive materials for

DOI: doi.org/10.1627/jpi.63.258

* To whom correspondence should be addressed.

* E-mail: ksuzuki@appchem.t.u-tokyo.ac.jp application such as catalysis, photocatalysis, energy conversion, and sensors ${ }^{5) \sim 7)}$. POMs are molecular inorganic compounds, and the main characteristics of their structures and properties include the following four points: (i) structures, sizes, constituent elements, and charges can be precisely controlled, (ii) part of constituent elements can be replaced with different elements, (iii) their properties (e.g., acid strength and redox potential) can be controlled by selecting their constituent elements and structures, and (iv) solubility can be controlled by selecting counter cations, and crystalline solids with three-dimensional arrays can be constructed by solidification.

To prepare functional inorganic materials, lacunary POMs possessing vacant sites (i.e., coordination sites) are useful inorganic multidentate ligands that can accommodate various metal cations with controlled number and position. This paper reports on our recent research on the development of precise synthesis method of nano-sized metal oxide catalysts using POMs (Fig. 1). Specifically, lacunary POMs were used as multidentate ligands or molecular templates in organic solvents to synthesize molecular metal oxides that freely designed their structures and functions. In addition to using POMs as simple molecular templates, using the synergistic effect of POMs and introduced metals or substrates, we pioneered a new methodology in the design of metal oxide catalysts, including the development of catalysts with new reactivities and visible-light- 


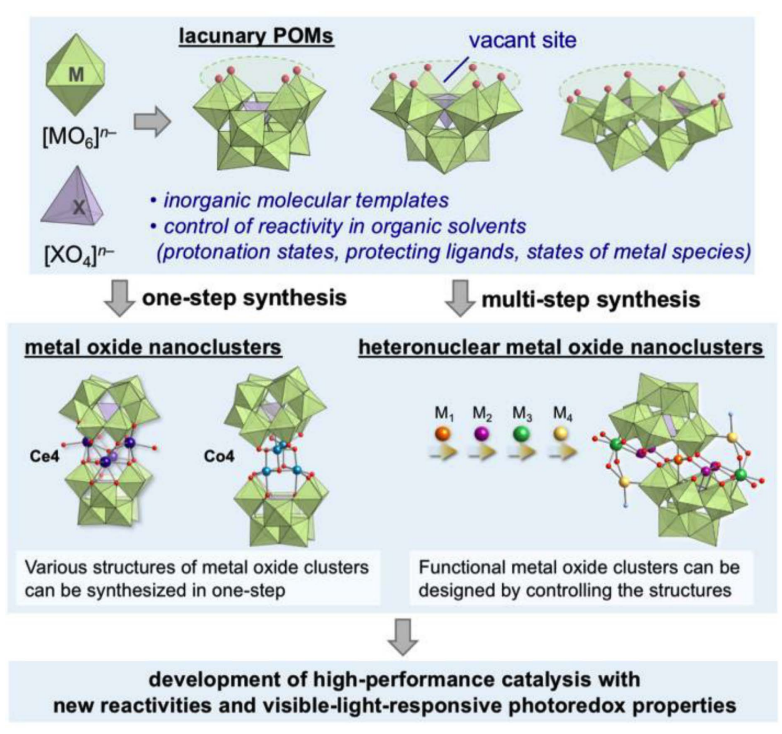

Fig. 1 New Strategy for Synthesizing POM Catalysts with Precisely Engineered Active Site Structures by Using Lacunary POMs

responsive photoredox catalysts for liquid-phase organic functional group transformations.

\section{Molecular Design of POMs}

Several types of POMs are partially hydrolyzed in an aqueous solution to form lacunary POMs in which one or more $\left\{\mathrm{MO}_{6}\right\}$ units were removed ${ }^{3)}$. The number and position of missing $\left\{\mathrm{MO}_{6}\right\}$ units can be controlled by the reaction conditions such as $\mathrm{pH}$ and concentration. Lacunary POMs can be used as inorganic multidentate ligands because their vacant sites are highly reactive to various metal ions. Specifically, using multi-vacant lacunary POMs, in which several $\left\{\mathrm{MO}_{6}\right\}$ units are removed, it is possible to synthesize various polynuclear metal oxide clusters that can act as catalytically active sites and functional materials ${ }^{8)}$. However, the reaction between lacunary POMs and metal ions has been typically carried out in an aqueous solution by empirically controlling reaction conditions (e.g., $\mathrm{pH}$, mixing ratio, and temperature), which frequently makes it difficult to control complex equilibrium in the solution. Therefore, it is generally difficult to isolate a single species other than the thermodynamically most stable structure. In addition, during the synthesis in an aqueous solution, the design of products is difficult because the structures of lacunary POMs sometimes change during the reaction with metal ions.

However, we have focused on the use of POMs in organic solvents by selecting appropriate counter cations such as the tetra- $n$-butyl ammonium (TBA) cation. Thus, a reaction between lacunary POMs and metal cations in organic solvents becomes possible. In organic solvents, the hydrolysis of lacunary POMs is signifi-

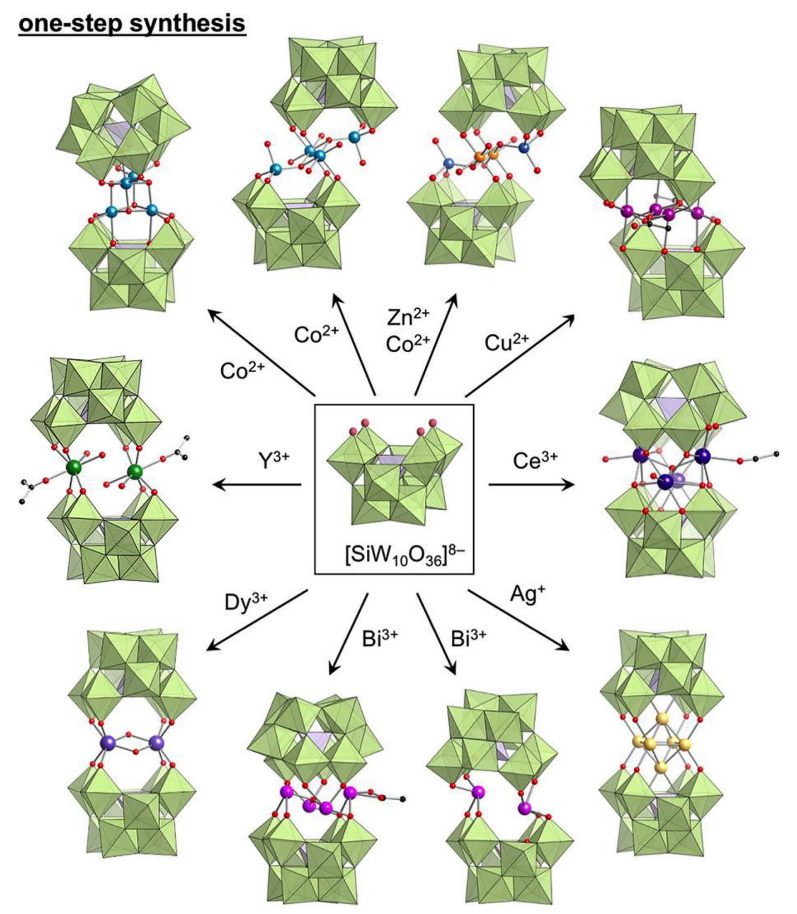

Fig. 2 One-step Synthesis of Active Site Structures by Reacting Divacant Lacunary POM $\left[\mathrm{SiW}_{10} \mathrm{O}_{36}\right]^{8-}$ and Metal Cations in Organic Solvents

cantly suppressed. In addition, oxygen atoms at the vacant sites of lacunary POMs are protonated (e.g., W$\mathrm{OH}_{2}$ and $\mathrm{W}-\mathrm{OH}$ ) and exhibit high basicity and high reactivity to metal ions. Importantly, the amount and position of protons can be stoichiometrically controlled; thus, it is possible to control the reactivity of lacunary POMs and to perform stoichiometric reactions with metal ions. Therefore, various transition metals, typical elements, and rare earth metals $\left(\right.$ e.g. $, \mathrm{Ti}^{4+}, \mathrm{Cu}^{2+}$, $\mathrm{Co}^{2+}, \mathrm{Zn}^{2+}, \mathrm{Ag}^{+}, \mathrm{Bi}^{3+}, \mathrm{Y}^{3+}, \mathrm{Ce}^{3+}, \mathrm{Nd}^{3+}$, and $\mathrm{Dy}^{3+}$ ) can be stoichiometrically introduced into lacunary POMs in one step, and the positions and number of metal atoms can be controlled to precisely arrange various polynuclear metal oxide clusters (Fig. 2) $)^{9) \sim 15)}$. For example, $\mathrm{Y}^{3+}$-containing $\mathrm{POM}^{10)}$ and $\mathrm{Ce}^{3+}$ containing $\mathrm{POM}^{12)}$ can be synthesized by reacting divacant lacunary Keggin-type POM $\left(\mathrm{TBA}_{4} \mathrm{H}_{4}\left[\mathrm{SiW}_{10} \mathrm{O}_{36}\right]\right)$ with $\mathrm{Y}(\mathrm{acac})_{3}(\mathrm{acac}=$ acetylacetonate $)$ and $\mathrm{Ce}(\mathrm{acac})_{3}$, respectively, in acetone according to the following equations (Eqs. (1) and (2)).

$$
\begin{aligned}
& 2 \mathrm{TBA}_{4} \mathrm{H}_{4}\left[\mathrm{SiW}_{10} \mathrm{O}_{36}\right]+2 \mathrm{Y}^{3+} \rightarrow \\
& \mathrm{TBA}_{8} \mathrm{H}_{2}\left[\mathrm{Y}_{2}\left(\mathrm{SiW}_{10} \mathrm{O}_{36}\right)_{2}\right]+6 \mathrm{H}^{+} \\
& 2 \mathrm{TBA}_{4} \mathrm{H}_{4}\left[\mathrm{SiW}_{10} \mathrm{O}_{36}\right]+4 \mathrm{Ce}^{3+}+3 \mathrm{H}_{2} \mathrm{O}+2 \mathrm{CH}_{3} \mathrm{CN} \rightarrow \\
& \mathrm{TBA}_{6}\left[\left\{\mathrm{Ce}\left(\mathrm{H}_{2} \mathrm{O}\right)\right\}_{2}\left\{\mathrm{Ce}\left(\mathrm{CH}_{3} \mathrm{CN}\right)\right\}_{2}\left(\mu_{4}-\mathrm{O}\right)\left(\mathrm{SiW}_{10} \mathrm{O}_{36}\right)_{2}\right] \\
& +2 \mathrm{TBA}^{+}+10 \mathrm{H}^{+}
\end{aligned}
$$

Furthermore, when reacting hexavacant lacunary Dawson-type POM $\left(\left[\mathrm{P}_{2} \mathrm{~W}_{12} \mathrm{O}_{48}\right]^{14-}\right)$ containing two 


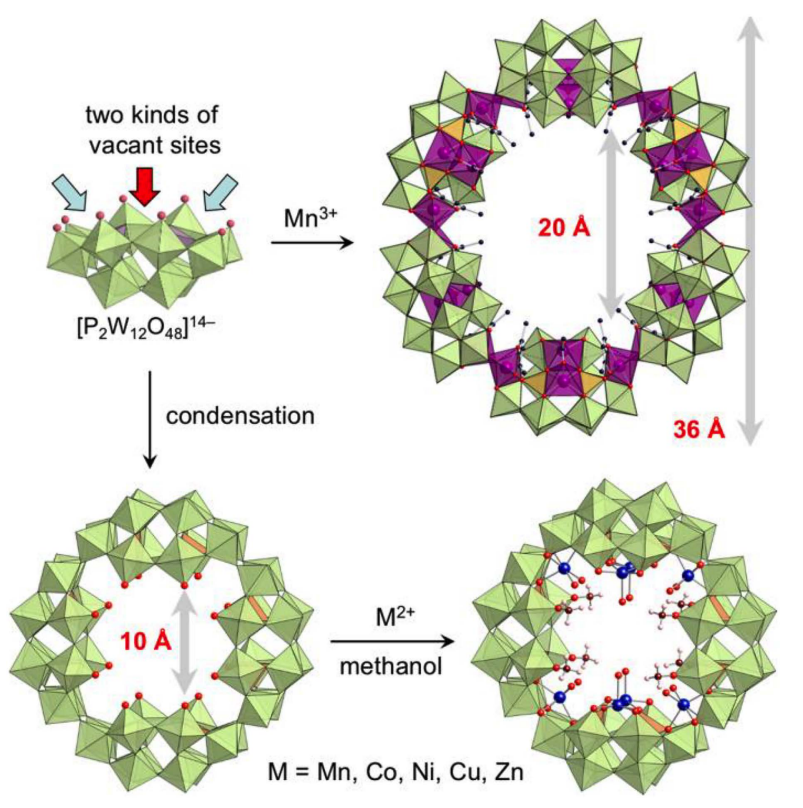

Fig. 3 Synthesis of Ring-shaped POMs and Arrangement of 3d Metal Ions in the Ring-shaped POMs

types of vacant sites with $\mathrm{Mn}^{3+}$ ions, it is possible to synthesize a giant ring-shaped POM, $\left[\left\{\gamma-\mathrm{P}_{2} \mathrm{~W}_{12} \mathrm{O}_{48}\right.\right.$ $\left.\left.\mathrm{Mn}_{4}(\mathrm{acac})_{2}(\mathrm{OAc})\right\}_{6}\right]^{42-}$ containing a nanopore with a diameter of ca. $20 \AA$ (Fig. 3 ${ }^{16)}$. This giant hexamer was disassembled into monomeric units in acetonitrile, and the removal of capping organic ligands on manganese cations led to reassembly and yielded tetrameric ring-shaped POM $\left[\left\{\gamma-\mathrm{P}_{2} \mathrm{~W}_{12} \mathrm{O}_{48} \mathrm{Mn}_{4}\left(\mathrm{H}_{2} \mathrm{O}\right)_{6}\right\}_{4}\left(\mathrm{H}_{2} \mathrm{O}\right)_{4}\right]^{24-}$.

A ring-shaped lacunary $\mathrm{POM}\left[\mathrm{P}_{8} \mathrm{~W}_{48} \mathrm{O}_{184}\right]^{40-}$, which is formed by the condensation of four hexavacant lacunary Dawson-type $\left[\mathrm{P}_{2} \mathrm{~W}_{12} \mathrm{O}_{48}\right]^{14-}$ units, is an attractive superlacunary POM possessing a large cavity (ca. $10 \AA$ ). In an aqueous media using the $\mathrm{K}^{+} / \mathrm{Li}^{+}$salt of the ring-shaped lacunary POM, we encountered several difficulties in introducing metal cations owing to the presence of $\mathrm{K}^{+}$and/or $\mathrm{Li}^{+}$cations. In contrast, using the TBA salt of ring-shaped POM $\left[\mathrm{P}_{8} \mathrm{~W}_{48} \mathrm{O}_{184}\right]^{40-}$, we can precisely arrange $3 \mathrm{~d}$ metal cations, such as $\mathrm{Mn}^{2+}$, $\mathrm{Co}^{2+}, \mathrm{Ni}^{2+}, \mathrm{Cu}^{2+}$, and $\mathrm{Zn}^{2+}$, inside the cavity (Fig. 3) ${ }^{17)}$.

In organic solvents, lacunary POMs and metal ions can be stoichiometrically reacted; thus, it is possible to selectively arrange different types of metal ions in one molecule by multi-step sequential reactions (Fig. 4) ${ }^{15), 18) \sim 20)}$. For example, by reacting Keggintype trivacant lacunary POM $\left[\mathrm{SiW}_{9} \mathrm{O}_{34}\right]^{10-}$ with metal ion (e.g., $\mathrm{Cr}^{3+}, \mathrm{Mn}^{3+}, \mathrm{Fe}^{3+}, \mathrm{Co}^{2+}, \mathrm{Ni}^{2+}, \mathrm{Cu}^{2+}, \mathrm{Ga}^{3+}$ ) in a molar ratio of $2: 1$, a mononuclear metal ion was introduced while leaving part of the vacant sites ${ }^{21)}$. By sequentially reacting transition metal ions (e.g., $\mathrm{Mn}^{3+}$, $\left.\mathrm{Ag}^{+}\right)$and rare earth metal ions (e.g., $\mathrm{Gd}^{3+}, \mathrm{Dy}^{3+}, \mathrm{Lu}^{3+}$ ) with this $\mathrm{Fe}^{3+}$-containing mononuclear structure, heteromultinuclear metal oxide clusters consisting of various metal arrangements and compositions (e.g., pentanuclear,

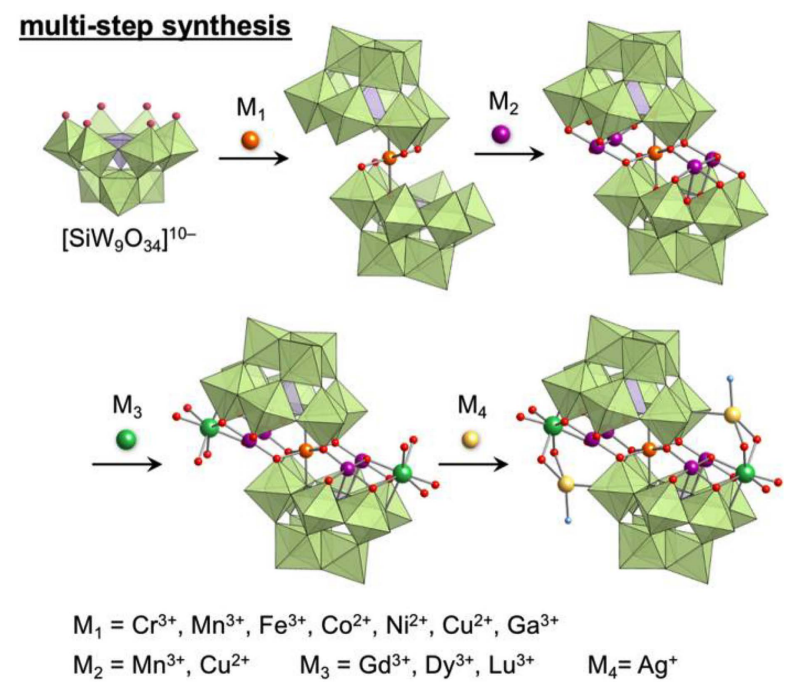

Fig. 4 Multi-step Synthesis of Active Site Structures by Sequentially Reacting Trivacant Lacunary POM $\left[\mathrm{SiW}_{9} \mathrm{O}_{34}\right]^{10^{-}}$and Metal Cations in Organic Solvents

heptanuclear, and nonanuclear clusters) were selectively obtained ${ }^{15), 19), 20)}$. Therefore, it is possible to design metal oxide clusters in which various types of metals are precisely arranged. These materials exhibit unique magnetic properties and single-molecule magnetic properties by controlling magnetic anisotropy and spin state according to the type and arrangement of metals. For example, $\mathrm{FeMn}_{4} \mathrm{Lu}_{2}$ cluster showed the notable slow magnetic relaxation in the alternating current (ac) magnetic susceptibility measurements, which is characteristic for single molecule magnets (Fig. 5).

Because lacunary POMs have high reactivity, their undesired self-condensation reaction or structural change may sometimes proceed even in organic solvents ${ }^{22)}$. Thus, reactivity can be controlled using alcohol or pyridine molecules as temporary protecting groups at the vacant sites ${ }^{23), 24)}$. For example, lacunary phosphomolybdates, such as a trivacant lacunary $\left[\mathrm{PMo}_{9} \mathrm{O}_{34}\right]^{9-}$, are extremely unstable and easily undergo structural transformation (or isomerization) even in organic solvents. Notably, the coordination of pyridine molecules to vacant sites significantly improved the stability of $\left[\mathrm{PMo}_{9} \mathrm{O}_{34}\right]^{9-}$ in solutions. In addition, inorganic-organic hybrid structures can be designed using the reversible binding of these organic groups to the vacant sites of $\mathrm{POMs}^{24}$. A dimer $\left(\mathrm{TBA}_{6}\right.$ $\left.\left.\left[\left(\mathrm{PMo}_{9} \mathrm{O}_{31}\right)_{2} \text { (bpy }\right)_{3}\right]\right)$ and tetramer $\left(\mathrm{TBA}_{10} \mathrm{H}_{2}\right.$ $\left.\left[\left(\mathrm{PMo}_{9} \mathrm{O}_{31}\right)_{4}(\mathbf{t p y p})_{2}(\text { pyridine })_{4}\right]\right)$ can be synthesized by reacting pyridine-coordinating $\mathrm{POM}\left(\mathrm{TBA}_{3}\right.$ [PMog $\mathrm{O}_{31}$ (pyridine) $\left.)_{3}\right]$ ) with 4,4'-bipyridine (bpy) and 5,10,15,20-tetra(4-pyridyl)porphyrin (tpyp), respectively (Eqs. (3) and (4); Fig. 6). 

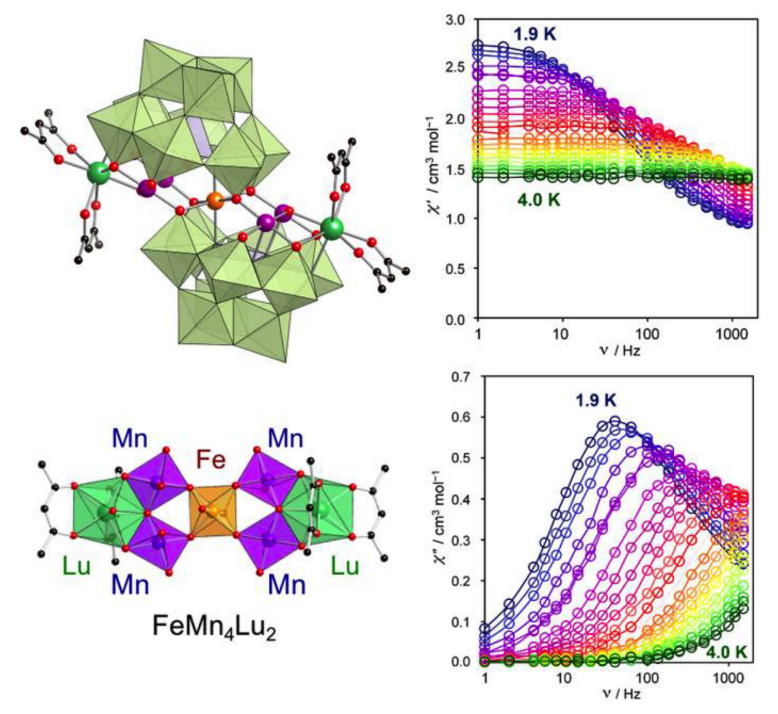

Fig. 5 Frequency Dependence of the In-phase $\left(\chi \chi^{\prime}\right)$ and Out-ofphase $\left(\chi\right.$ ') ac Magnetic Susceptibility of $\mathrm{FeMn}_{4} \mathrm{Lu}_{2}$ Cluster under the Zero Applied dc Field in the Temperature Range of $1.9-4.0 \mathrm{~K}$

$$
\begin{aligned}
& 2 \mathrm{TBA}_{3}\left[\mathrm{PMo}_{9} \mathrm{O}_{31}(\text { pyridine })_{3}\right]+3 \mathbf{b p y} \rightarrow \\
& \mathrm{TBA}_{6}\left[\left(\mathrm{PMo}_{9} \mathrm{O}_{31}\right)_{2}(\mathbf{b p y})_{3}\right] \\
& 4 \mathrm{TBA}_{3}\left[\mathrm{PMo}_{9} \mathrm{O}_{31}(\text { pyridine })_{3}\right]+2 \text { tpyp }+2 \mathrm{H}^{+} \rightarrow \\
& \mathrm{TBA}_{10} \mathrm{H}_{2}\left[\left(\mathrm{PMo}_{9} \mathrm{O}_{31}\right)_{4}(\text { tpyp })_{2}(\text { pyridine })_{4}\right]+2 \mathrm{TBA}^{+} \\
& +8 \text { pyridine }
\end{aligned}
$$

Of note, metal nanoclusters with interactions between metals (for example, $\left\{\mathrm{Ag}_{27}\right\}$ nanocluster) can be synthesized using the synthetic method in organic solvents (Fig. 7 $)^{25)}$. Specifically, $N, N$-dimethylformamide (DMF) acted as a mild reducing reagent for $\mathrm{Ag}^{+}$ions for the synthesis of silver nanoclusters.

By taking advantage of various coordination structures of lacunary POMs, we developed inorganic materials that reversibly changed their structures in response to external stimuli. For example, we synthesized a dinuclear $\mathrm{Dy}^{3+}$ structure that could switch the properties of a single-molecule magnet by the addition of an acid or base (Fig. 8a) ${ }^{26)}$, and a tetranuclear $\mathrm{Co}^{2+}$ structure that could reversibly convert structures, color, and magnetic properties according to the changes in water content and temperature (Fig. $8 \mathbf{b b})^{27)}$.

\section{Design of POM Catalysts by Synergetic Effects}

On the basis of the abovementioned synthetic strategy of molecular metal oxides, we developed highperformance catalysts for various liquid-phase functional group transformations using the synergetic effects of POMs and introduced metals. For example, POMs containing rare earth metals, such as $\mathrm{Y}^{3+}$ and $\mathrm{Nd}^{3+}$, possessed Lewis acid sites (rare earth metal ions) and
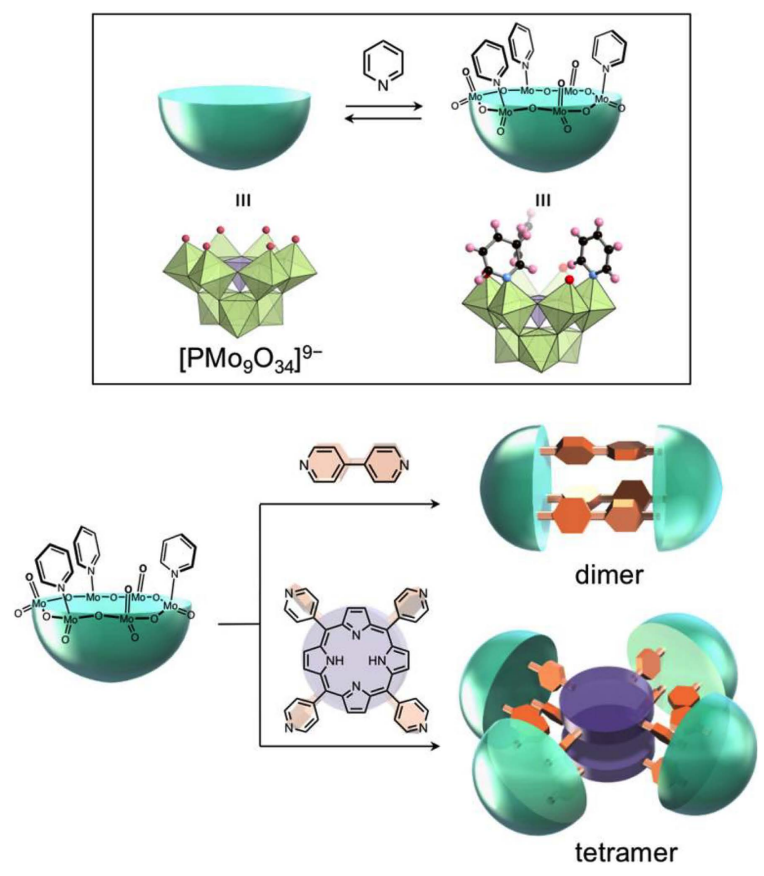

Fig. 6 Design of Inorganic-organic Hybrid Structures by Utilizing Pyridyl Coordination to the Vacant Sites of Lacunary POMs

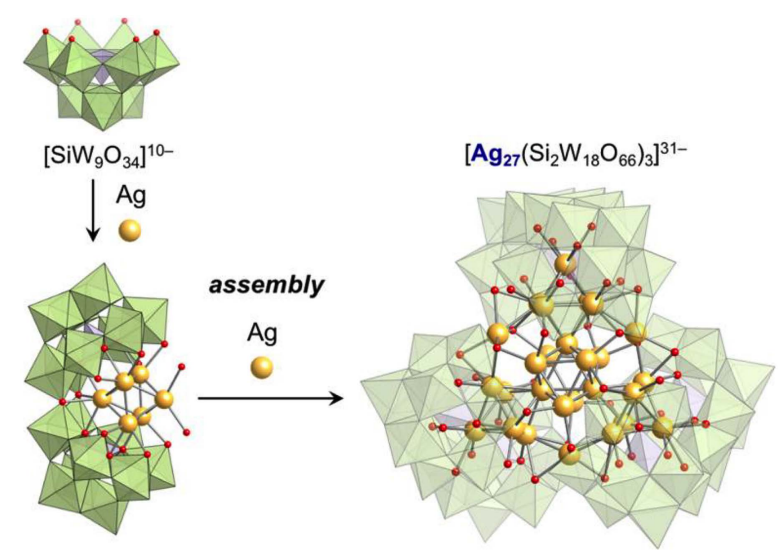

Fig. 7 Synthesis of Ag Nanoclusters within Lacunary POMs

base sites (POMs), which coexisted in the molecule; these metals could activate substrates in a concerted manner (Fig. 9) ${ }^{10), 28)}$. Therefore, compared to the case of separately using rare earth metal ions and POMs as catalysts, POMs containing rare earth metals showed a dramatically improved catalytic activity for the cyanosilylation of carbonyl compounds by the synergetic effect of Lewis acid and base in POMs using trimethylsilyl cyanide (TMSCN) as the cyano source. POMs with larger rare earth metal cations exhibited higher catalytic activities owing to the sterically less hindered Lewis acid sites and the higher activation ability of $\mathrm{C}=$ $\mathrm{O}$ bonds. Among the examined POM catalysts, neodymium-containing POM $\left(\mathrm{TBA}_{8} \mathrm{H}_{2}\left[\mathrm{Nd}_{2}\left(\mathrm{SiW}_{10} \mathrm{O}_{36}\right)_{2}\right]\right.$, $\mathrm{Nd}-\mathrm{POM}$ ) showed a remarkable catalytic performance 
a)

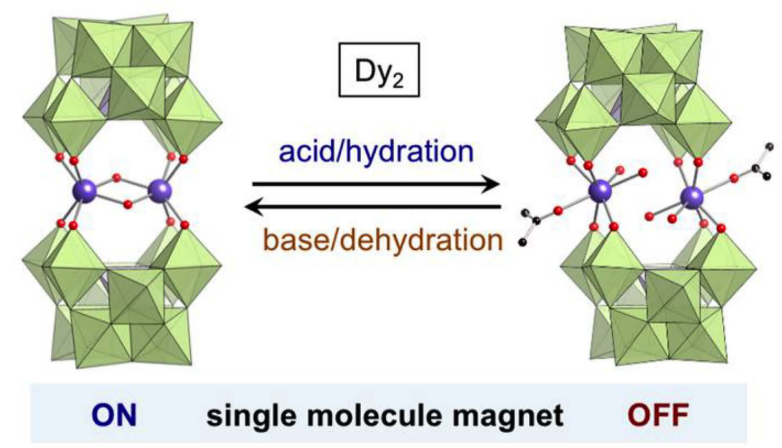

b)
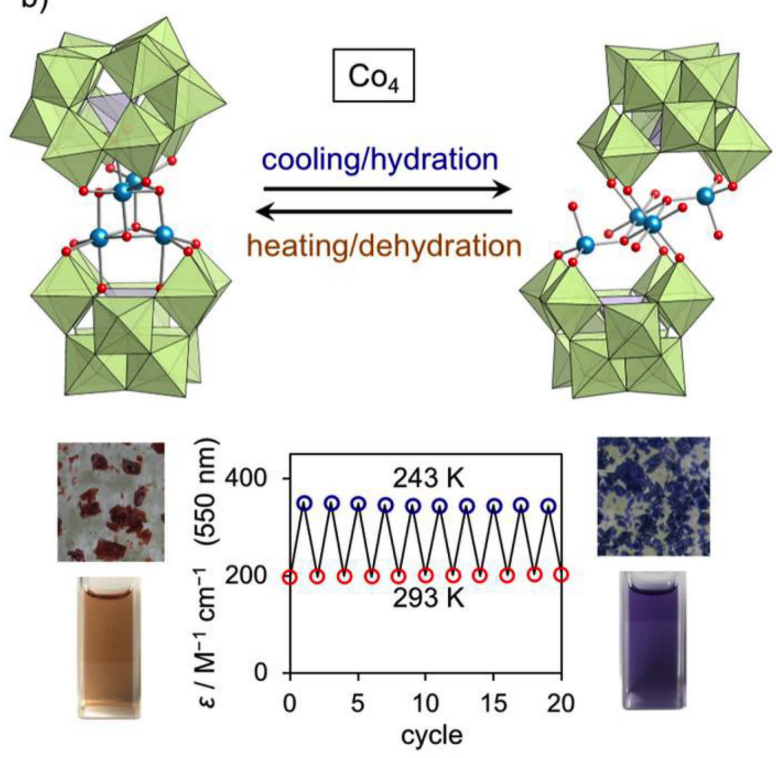

a) Switching of single-molecule magnet properties by structure transformation of dinuclear $\mathrm{Dy}^{3+}$-containing POMs, b) switching of optical properties by structure transformation of tetranuclear $\mathrm{Co}^{2+}$-containing POMs.

Fig. 8 Stimuli-responsive Structure Transformation of POMs

for the cyanosilylation of various types of structurally diverse ketones and aldehydes (Fig. 9). Specifically, the turnover frequency $\left(714,000 \mathrm{~h}^{-1}\right)$ and turnover number $(23,800)$ for the cyanosilylation of $n$-hexanal were of the highest level among those of previously reported catalysts.

In addition, catalysts incorporating multinuclear metal cores (e.g., Ti, Ag, and V) exhibited high catalytic activity for various selective oxidation reactions. For example, vanadium-containing heteropoly acids showed high activity for the regioselective cyanation of quinoline molecules and trifluoromethylation of aromatic compounds using an acid and oxidizing properties in a concerted manner ${ }^{29)}$.

POMs are promising materials as photocatalysts owing to their ability to store multiple electrons and protons in one molecule and the ability to exhibit re-

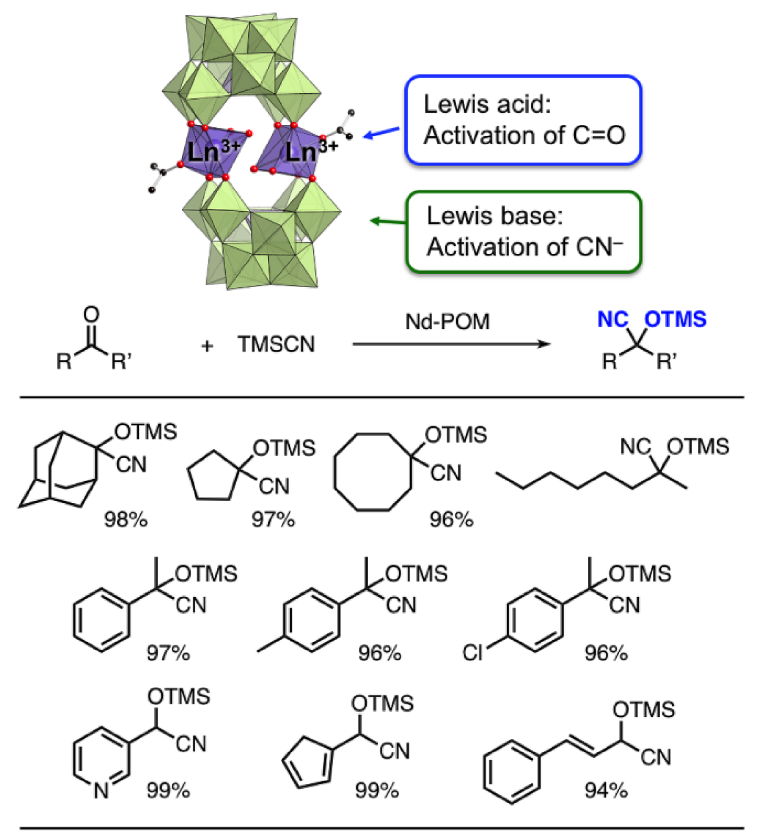

Conditions: Nd-POM (0.5 mol\%), ketone $(0.25 \mathrm{mmol}), \mathrm{TMSCN}(0.375 \mathrm{mmol})$, acetonitrile $(1.0 \mathrm{~mL}), 30^{\circ} \mathrm{C}$

Fig. 9 Cyanosilylation of Carbonyl Compounds by the Concerted Catalysis of Lewis Acid and Base of POMs Containing Rare Earth Metals

versible oxidation-reduction (redox) reactions and photoresponsive charge transfer ${ }^{30}$. In addition, POM frameworks are typically stable during photoredox reactions. Furthermore, the redox potentials of POMs can be controlled by changing their structures and constituent elements or by the introduction of additional metal cations into the POM framework. Thus, POM-based photocatalysts have several advantages over other photoredox catalysts such as organic dyes ${ }^{31)}$ and organometallic coordination complexes ${ }^{32) \sim 34)}$. Various photocatalytic organic synthesis reactions using ultraviolet (UV) light as the driving force have been developed using a TBA salt of decatungstate $\left[\mathrm{W}_{10} \mathrm{O}_{32}\right]^{4-}$ as a photocatalyst ${ }^{30}$. The TBA salt of decatungstate is commercially available, and many organic synthesis chemists has recently utilized it for various functional group transformations. Excellent review papers have recently been reported by Orfanopoulos ${ }^{35)}$ and $\mathrm{Ryu}^{36)}$ in these fields.

However, one of the problems in the photoreaction using polyoxotungstates is that their photo-excitation requires irradiation with a UV light. For example, Keggin-type divacant lacunary POM $\left[\mathrm{SiW}_{10} \mathrm{O}_{36}\right]^{8-}$ has the highest occupied molecular orbital on the $\mathrm{O}$ atoms (HOMO, O2p) and the lowest unoccupied molecular orbital on $\mathrm{W}$ atoms (LUMO, W5d). The energy gap between HOMO and LUMO is large $\left(E_{\mathrm{g}}>4.0 \mathrm{eV}\right)$. Therefore, this POM cannot be excited by visible light, and irradiation with UV light corresponding to this energy is required.

However, POMs possessing multinuclear metal cores 


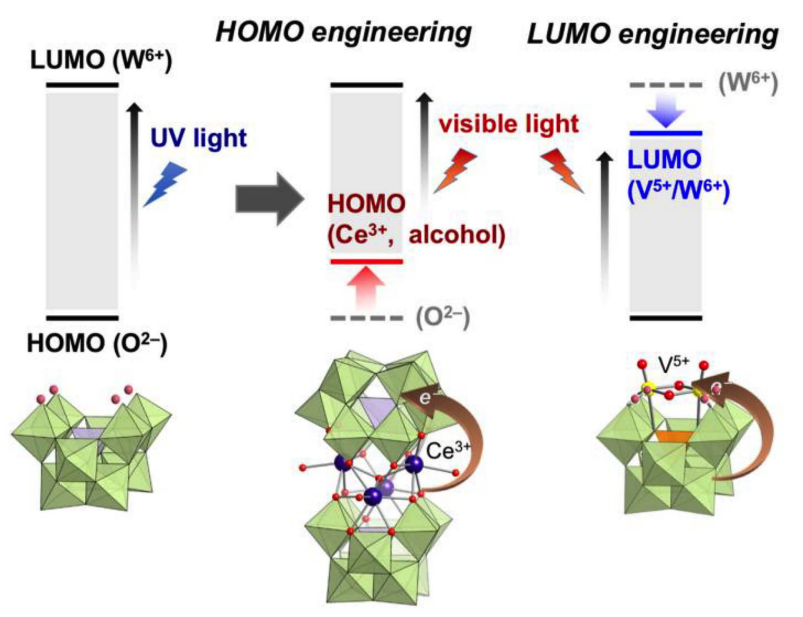

Fig. 10 Design of Visible-light-responsive POM Photocatalysis by HOMO- and LUMO-engineering Strategies Using Lacunary POMs

enable visible-light-responsive intramolecular charge transfer, and they can be used as visible-light-responsive oxidation catalysts. For example, in POM $\left[\left\{\mathrm{Ce}\left(\mathrm{H}_{2} \mathrm{O}\right)\right\}_{2}\right.$ $\left.\left\{\mathrm{Ce}\left(\mathrm{CH}_{3} \mathrm{CN}\right)\right\}_{2}\left(\mu_{4-} \mathrm{O}\right)\left(\mathrm{SiW}_{10} \mathrm{O}_{36}\right)_{2}\right]^{6-}(\mathrm{Ce}-\mathrm{POM})$ possessing a tetranuclear $\mathrm{Ce}^{3+}$ core, a new HOMO was formed on $\mathrm{Ce}^{3+}$, and the energy gap between HOMO and LUMO became significantly smaller (Fig. 10; HOMO engineering strategy $)^{12), 37), 38)}$. Thus, an absorption band attributable to the charge transfer from $\mathrm{Ce}^{3+}$ to the POM framework was observed at approximately $460 \mathrm{~nm}$. This catalyst can use visible light $(\lambda$ $>400 \mathrm{~nm}$ ) as a driving force and showed high activity for various aerobic photo-oxidation reactions (Fig. 11). For example, the oxidative dehydrogenations of primary and secondary amines efficiently proceeded by the visible-light-responsive photocatalysis of Ce-POM using $1 \mathrm{~atm}$ of $\mathrm{O}_{2}$ as the oxidant (Fig. 11a $)^{12)}$. In addition, various types of structurally diverse trialkylamines can react with TMSCN in the presence of $1 \mathrm{~mol} \% \mathrm{Ce}-\mathrm{POM}$, which affords the corresponding $\alpha$-amino nitriles $(\text { Fig. 11b })^{12)}$. Of note, monocyanated products were selectively obtained without the formation of di- and tricyanated products. The present photocatalytic system can be also applicable to the aerobic selective oxygenation of sulfides into sulfoxides (Fig. 11c) $)^{37)}$. On the basis of experimental data, we proposed the following reaction mechanism. Specifically, the reactions proceeded when $\mathrm{Ce}^{4+}$ species, which were generated by the visible-light-responsive charge transfer from $\mathrm{Ce}^{3+}$ to the tungsten oxide skeleton, oxidized amine with one electron. The catalytic cycle was established by the reoxidation of the reduced tungsten oxide skeleton by $\mathrm{O}_{2}$ (Fig. 11).

In the abovementioned photocatalyst design, a visible-light-responsive property was achieved by controlling HOMOs. Therefore, the problem is that the oxidizing power of photoexcited species is reduced, and
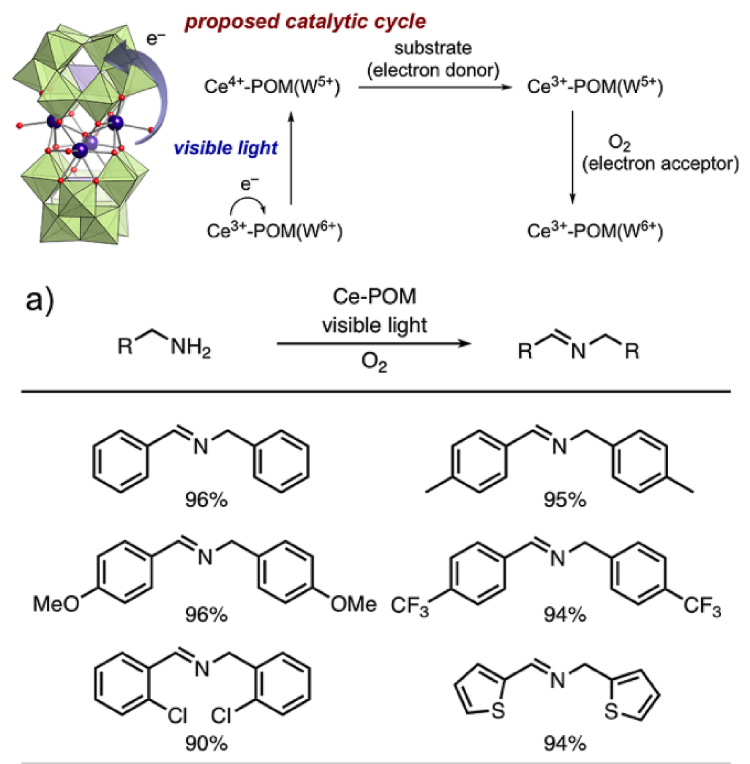

Conditions: Ce-POM (1 mol\%), amine $(0.2 \mathrm{mmol})$, acetonitrile $(2 \mathrm{~mL})$, visible light $(\lambda>400 \mathrm{~nm}), \mathrm{O}_{2}(1 \mathrm{~atm}), 30^{\circ} \mathrm{C}$

b)

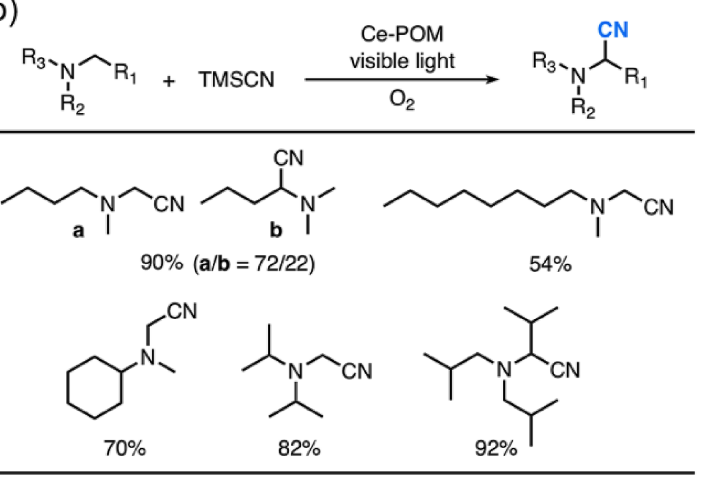

Conditions: Ce-POM ( 1 mol\%), amine $(0.2 \mathrm{mmol}), \operatorname{TMSCN}(0.4 \mathrm{mmol})$ acetonitrile $(2 \mathrm{~mL})$, visible light $(\lambda>400 \mathrm{~nm}), \mathrm{O}_{2}(1 \mathrm{~atm}), 30^{\circ} \mathrm{C}$

c)
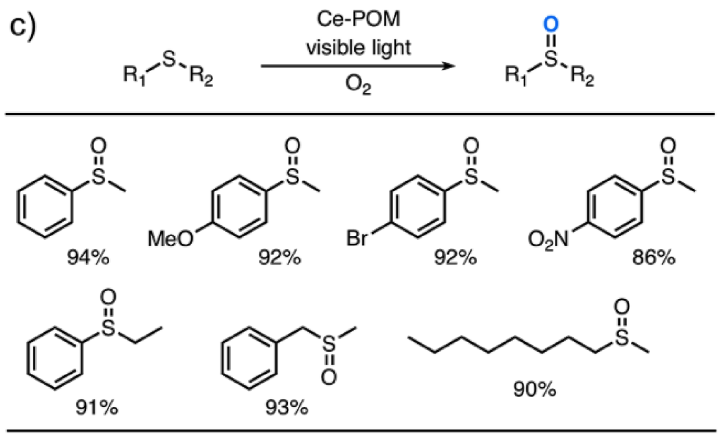

Conditions: Ce-POM (1 mol\%; in situ formed from $\mathrm{TBA}_{4} \mathrm{H}_{4}\left[\mathrm{SiW}_{10} \mathrm{O}_{36}\right]$ and $\left.\mathrm{Ce}(\mathrm{acac})_{3}\right)$, sulfide $(0.2 \mathrm{mmol})$, acetonitrile/methanol $(1 \mathrm{~mL}, 2 / 1 \mathrm{v} / \mathrm{v})$, visible light $(\lambda>400 \mathrm{~nm}), \mathrm{O}_{2}(1 \mathrm{~atm}), 30^{\circ} \mathrm{C}$

a) Oxidative dehydrogenation of primary and secondary amines, b) oxidative $\alpha$-cyanation of tertiary amines, and selective oxygenation of sulfides into sulfoxides.

Fig. 11 Visible-light-induced Photo-oxidative Reactions Using Ce-POM Catalyst 
a new catalyst design is required to develop superb photo-oxidation catalysis. To solve this problem, it is possible to develop a catalyst containing both a visible-light-responsive property and high oxidizing power by designing LUMO of POMs. For example, by introducing a dinuclear $\mathrm{V}^{5+}$ core into lacunary POM, new LUMO (hybrid V3d/W5d orbital) was formed, and this catalyst exhibited high activity in the selective oxidation of sulfide to sulfoxide using $\mathrm{O}_{2}$ as the oxidant by irradiation with visible light (Fig. 10; LUMO engineering strategy) ${ }^{39)}$.

In addition to the coordination of metals, the visiblelight-responsive properties of POMs can be achieved by the coordination of alcohols ${ }^{40) \sim 42)}$. When divacant lacunary POM $\left[\mathrm{SiW}_{10} \mathrm{O}_{36}\right]^{8-}$ was irradiated with visible light in the presence of alcohol in organic solvents under Ar atmosphere, the solution became deep blue, and a new absorption band appeared at approximately $650 \mathrm{~nm}$. This absorption band was assignable to the intervalence charge transfer of $\mathrm{W}^{6+} / \mathrm{W}^{5+}$, which suggests the formation of a multielectron-reduced POM. At this time, a stoichiometric amount of the corresponding aldehyde was also formed, and it was determined that the multielectron transfer from the coordinating alcohol to POM proceeded by irradiation with visible light. When nitrobenzene was added to this blue solution, the solution became clear, and the reduction reaction of nitrobenzene to aniline proceeded. Thus, a reaction between aniline and aldehyde formed the corresponding $N$-arylimine (Fig. 12). Using this visible-light-responsive photocatalyst system, we succeeded in the selective multielectron reduction of nitrobenzene and sulfoxide using alcohol as a reducing agent (Fig. 13). Considering the reduction potential of sulfoxide, the reduction reaction of sulfoxide by lacunary POM is usually difficult. However, based on various experimental data, we determined that sulfoxides can be activated by coordinating to the vacant sites of lacunary POMs and efficiently and selectively reduced to corresponding sulfides ${ }^{37)}$. A proposed reaction mechanism is shown in Fig. 13. In these reduction reactions, it was possible to selectively reduce target functional groups even on substrates containing other and efficiently reduced functional groups such as $\mathrm{C}=\mathrm{C}, \mathrm{C} \equiv \mathrm{C}$, and halogen.

\section{Conclusions}

In this paper, we introduced the precise synthesis method of metal oxide nanoclusters using POMs in organic solvents toward the development of molecular (photo)catalysts for organic synthesis. In particular, the molecular design of POM catalysts led to the development of a high-performance catalyst that utilized synergetic effects and various selective photoredox reactions using visible-light-responsive photocatalysts.
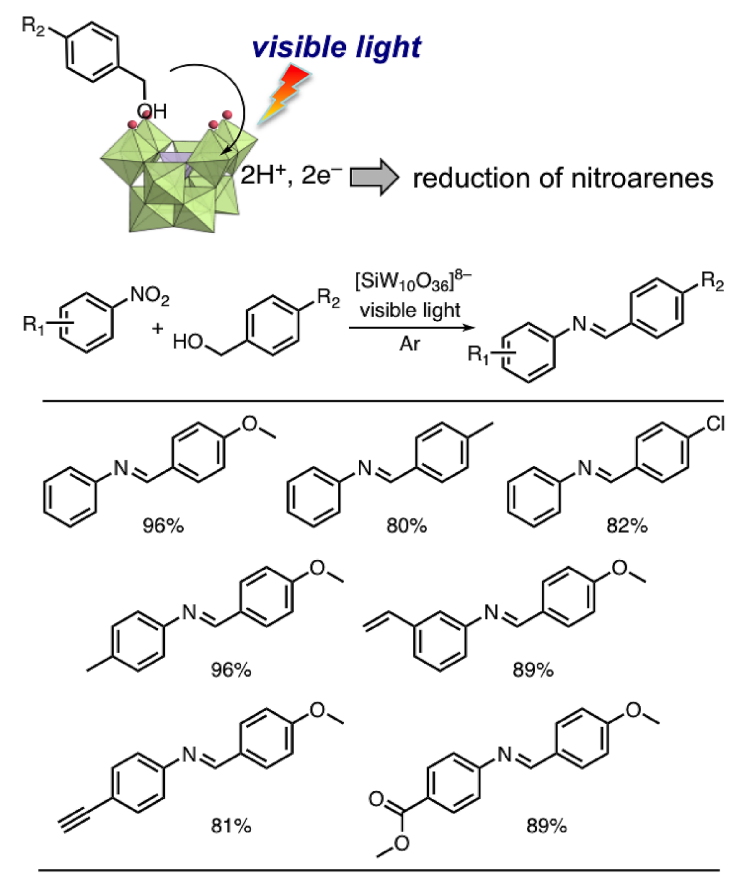

Conditions: $\mathrm{TBA}_{4} \mathrm{H}_{4}\left[\mathrm{SiW}_{10} \mathrm{O}_{36}\right](1 \mathrm{~mol} \%$ ), nitroarene $(0.2 \mathrm{mmol})$, alcohol (4 mmol), acetonitrile/toluene $(2 \mathrm{~mL}, 1 / 9 \mathrm{v} / \mathrm{v})$, visible light $(\lambda>400 \mathrm{~nm}), \operatorname{Ar}(1 \mathrm{~atm}), 60^{\circ} \mathrm{C}$

Fig. 12 Photocatalytic Synthesis of $\mathrm{N}$-arylimines through the Reduction of Nitrobenzenes by Visible-light-responsive Photocatalysis of Lacunary POM

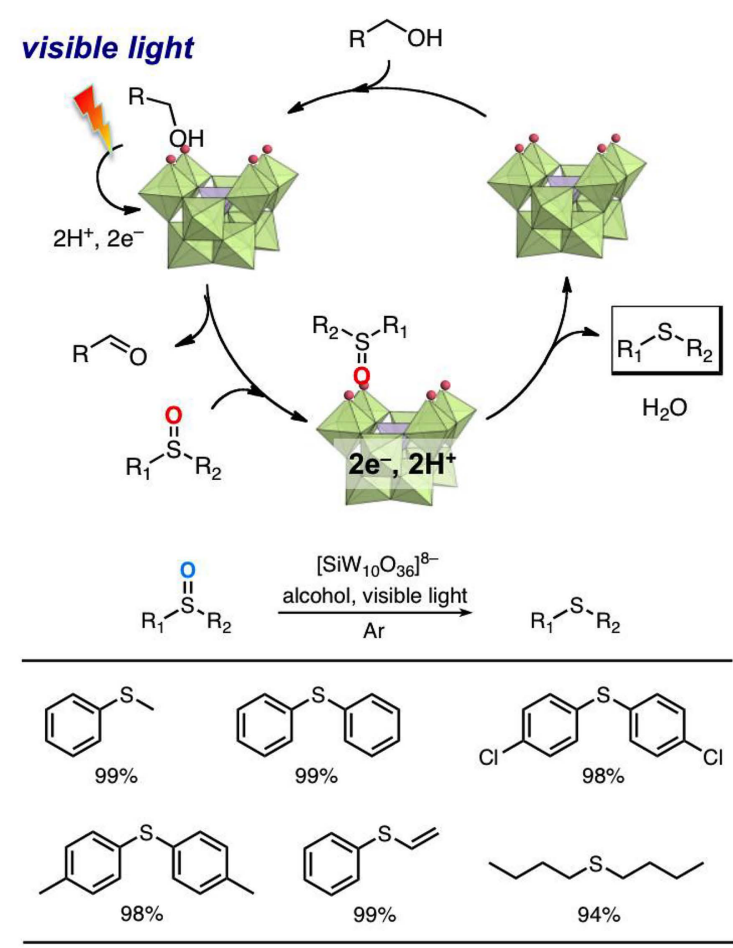

Conditions: $\mathrm{TBA}_{4} \mathrm{H}_{4}\left[\mathrm{SiW}_{10} \mathrm{O}_{36}\right](1 \mathrm{~mol} \%)$, sulfoxide $(0.2 \mathrm{mmol})$, alcohol (1 mmol), acetonitrile/toluene $(2 \mathrm{~mL}, 1 / 9 \mathrm{v} / \mathrm{v})$, visible light $(\lambda>400 \mathrm{~nm}), \operatorname{Ar}(1 \mathrm{~atm}), 30^{\circ} \mathrm{C}$

Fig. 13 Photocatalytic Reduction of Sulfoxides to Sulfides by Visible-light-responsive Photocatalysis of Lacunary POM 
We expect that these catalyst design methods will be applicable to the design of various molecular metal oxide catalysts and heterogeneous metal oxide catalysts.

\section{Acknowledgment}

This work was accomplished by the tremendous efforts of co-workers in our laboratory. This work was supported in part by JSPS KAKENHI Grant Numbers 18H04500, 17H03037, and JST PRESTO Grant Number JPMJPR18T7.

\section{References}

1) Ogale, S. B., Venkatesan, T. V., Blamire, M. G., "Functional Metal Oxides: New Science and Novel Applications," Wiley-VCH Verlag GmbH \& Co. KGaA, Weinheim (2013).

2) Jackson, S. D., Hargreaves, J. S. J., "Metal Oxide Catalysis," Wiley-VCH Verlag GmbH \& Co. KGaA, Weinheim (2019).

3) Pope, M. T., "Heteropoly and Isopoly Oxometalates," Springer, New York (1983).

4) Hill, C. L. ed., Polyoxometalates, Chem. Rev., 98, 1 (1998).

5) Miras, H. N., Yan, J., Long, D.-L., Cronin, L., Chem. Soc. Rev., 41, 7403 (2012).

6) Lv, H., Geletii, Y. V., Zhao, C., Vickers, J. W., Zhu, G., Luo, Z., Song, J., Lian, T., Musaev, D. G., Hill, C. L., Chem. Soc. Rev., 41, 7572 (2012).

7) Sadakane, M., Steckhan, E., Chem. Rev., 98, 219 (1998).

8) Zheng, S.-T., Yang, G.-Y., Chem. Soc. Rev., 41, 7623 (2012).

9) Suzuki, K., Kikukawa, Y., Uchida, S., Tokoro, H., Imoto, K., Ohkoshi, S.-I., Mizuno, N., Angew. Chem. Int. Ed., 51, 1597 (2012).

10) Kikukawa, Y., Suzuki, K., Sugawa, M., Hirano, T., Kamata, K., Yamaguchi, K., Mizuno, N., Angew. Chem. Int. Ed., 51, 3686 (2012).

11) Kikukawa, Y., Kuroda, Y., Suzuki, K., Hibino, M., Yamaguchi, K., Mizuno, N., Chem. Commun., 49, 376 (2013).

12) Suzuki, K., Tang, F., Kikukawa, Y., Yamaguchi, K., Mizuno, N., Angew. Chem. Int. Ed., 53, 5356 (2014).

13) Hanaya, T., Suzuki, K., Sato, R., Yamaguchi, K., Mizuno, N., Dalton Trans., 46, 7384 (2017).

14) Suzuki, K., Hanaya, T., Sato, R., Minato, T., Yamaguchi, K., Mizuno, N., Chem. Commun., 52, 10688 (2016).

15) Minato, T., Suzuki, K., Ohata, Y., Yamaguchi, K., Mizuno, N., Chem. Commun., 53, 7533 (2017).

16) Minato, T., Suzuki, K., Yamaguchi, K., Mizuno, N., Angew. Chem. Int. Ed., 55, 9630 (2016).

17) Sasaki, S., Yonesato, K., Mizuno, N., Yamaguchi, K., Suzuki, K., Inorg. Chem., 58, 7722 (2019).

18) Sato, R., Suzuki, K., Sugawa, M., Mizuno, N., Chem. Eur. J.,
19, 12982 (2013).

19) Suzuki, K., Sato, R., Minato, T., Shinoe, M., Yamaguchi, K., Mizuno, N., Dalton Trans., 44, 14220 (2015).

20) Sato, R., Suzuki, K., Minato, T., Yamaguchi, K., Mizuno, N., Inorg. Chem., 55, 2023 (2016).

21) Sato, R., Suzuki, K., Minato, T., Shinoe, M., Yamaguchi, K., Mizuno, N., Chem. Commun., 51, 4081 (2015).

22) Minato, T., Suzuki, K., Kamata, K., Mizuno, N., Chem. Eur. J., 20, 5946 (2014).

23) Minato, T., Suzuki, K., Yamaguchi, K., Mizuno, N., Chem. Eur. J., 23, 14213 (2017).

24) Li, C., Mizuno, N., Yamaguchi, K., Suzuki, K., J. Am. Chem. Soc., 141, 7687 (2019).

25) Yonesato, K., Ito, H., Itakura, H., Yokogawa, D., Kikuchi, T., Mizuno, N., Yamaguchi, K., Suzuki, K., J. Am. Chem. Soc., 141, 19550 (2019).

26) Suzuki, K., Sato, R., Mizuno, N., Chem. Sci., 4, 596 (2013).

27) Kuriyama, Y., Kikukawa, Y., Suzuki, K., Yamaguchi, K., Mizuno, N., Chem. Eur. J., 22, 3962 (2016).

28) Suzuki, K., Sugawa, M., Kikukawa, Y., Kamata, K., Yamaguchi, K., Mizuno, N., Inorg. Chem., 51, 6953 (2012).

29) Yamaguchi, K., Xu, N., Jin, X., Suzuki, K., Mizuno, N., Chem. Commun., 51, 10034 (2015).

30) Suzuki, K., Mizuno, N., Yamaguchi, K., ACS Catal., 8, 10809 (2018).

31) Romero, N. A., Nicewicz, D. A., Chem. Rev., 116, 10075 (2016).

32) Prier, C. K., Rankic, D. A., MacMillan, D. W. C., Chem. Rev., 113, 5322 (2013).

33) Narayanama, J. M. R., Stephenson, C. R. J., Chem. Soc. Rev., 40, 102 (2011).

34) Shaw, M. H., Twilton, J., MacMillan, D. W. C., J. Org. Chem., 81, 6898 (2016).

35) Tzirakis, M. D., Lykakis, I. N., Chem. Soc. Rev., 38, 2609 (2009).

36) Ravelli, D., Fagnoni, M., Fukuyama, T., Nishikawa, T., Ryu, I., ACS Catal., 8, 701 (2018).

37) Suzuki, K., Jeong, J., Yamaguchi, K., Mizuno, N., New J. Chem., 40, 1014 (2016).

38) Suzuki, K., Tang, F., Kikukawa, Y., Yamaguchi, K., Mizuno, N., Chem. Lett., 43, 1429 (2014).

39) Li, C., Suzuki, K., Mizuno, N., Yamaguchi, K., Chem. Commun., 54, 7127 (2018).

40) Suzuki, K., Jeong, J., Yamaguchi, K., Mizuno, N., Chem. Asian J., 10, 144 (2015).

41) Jeong, J., Suzuki, K., Yamaguchi, K., Mizuno, N., New J. Chem., 41, 13226 (2017).

42) Jeong, J., Suzuki, K., Hibino, M., Yamaguchi, K., Mizuno, N., ChemistrySelect, 1, 5042 (2016).

43) Suzuki, K., Yamaguchi, K., Mizuno, N., Chem. Lett., 46, 1379 (2017). 
要 旨

\title{
精密設計された活性点構造を有するポリオキソメタレート触媒の合成における新戦略
}

\author{
鈴木 康介, 水野 哲孝, 山口 和也
}

東京大学大学院工学系研究科, 113-8656 東京都文京区本郷7-3-1

高効率, 高選択性の化学反応や高難度反応を実現するために は, 一原子単位で構造や機能を精密設計する新しい触媒技術の 開発が不可欠である。本稿では, 分子状金属酸化物であるポリ オキソメタレート触媒の精密合成法と, その有機合成反応への 利用に関する研究を紹介する。特に, 配位サイトを有する欠損 型ポリオキソメタレートを分子鋳型や多座配位子として用い て, 構造や機能を自在設計する精密無機合成法を確立し, 同一 種だけでなく異種金属を選択的・逐次的に精密配列する無機合
成を可能にした。有機溶媒中において反応部位のプロトン化状 態の制御や，金属種の溶存状態の制御により，傊型ポリオキ ソメタレートの反応性制御が可能になり, 様々な金属を核数, 配列, 結合様式などを制御した無機材料設計ができる。さら に，ポリオキソメタレートに導入する金属や基質との協奏作用 を利用して, 既存の触媒を超える活性や新たな反応性の発現, 分子内電荷移動を利用した可視光応答型酸化還元触媒の開発な ど，金属酸化物触媒の設計における新たな方法論を開拓した。 